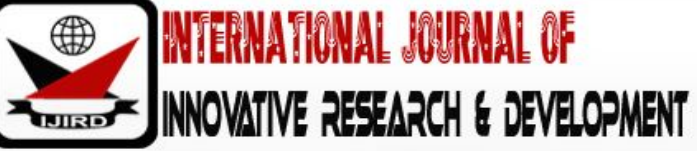

ISSN 2278 - 0211 (Online)

\section{Rural Electrification and Energy Poverty in Maza Village, Plateau State, Nigeria}

\author{
Nesla Asheazi Ruth \\ Assistant Lecturer, Department of Geography and Planning, University of Jos, Nigeria \\ Gonap Elisha Gobin \\ Lecturer, Department of Hospitality and Tourism Management, Federal University Wukari, Nigeria
}

\begin{abstract}
:
Access to adequate, clean reliable, sustainable and modern energy sources is a priority for economic development and poverty alleviation, provision and access to such energy sources has continued to be a challenge in many rural communities in Plateau State. This paper sought to assess rural electrification and energy poverty in Maza village. Systematic random sampling techniques was adopted where 150 houses hold out of the estimated 1250 households were selected for questionnaire administration. Apart from the structural questionnaire, the paper made use of interviews and reconnaissance survey for data collection. Simple descriptive statistics was used to analyse and present the result of the data collected and coded. The paper found out that the residents of Maza village are energy poor as they have limited energy options, in the absence of electricity, residents are forced to rely on traditional energy source like firewood and charcoal for heating and cooking. The paper recommend that government should partner with private sector to extend power supply to rural areas and also device and also advice other sustainable and renewable energy sources like wind and solar energy.
\end{abstract}

Keywords: Rural area, electrification

\section{Introduction}

Access to electricity is fundamental to human welfare. We need energy to cook our food and heat our homes. We use illumination after the sun goes down to extend out productive hour and provide us with huge improvements in quality of life. Beyond these basic functions, we rely on energy to provide services such as telecommunication, health care, and education as well as many of the conveniences available to people in modern economics. Without access to electricity, household are forced to rely on polluting and dangerous sources of energy such as the burning of firewood, dung, charcoal and kerosene.

Electricity is a basic part of nature and is one of our mostly widely used forms of energy. We get electricity, which is a secondary energy source from the conversion of other sources of energy, like coal, natural gas, oil, nuclear power, water and other natural sources, which are called primary sources. Access to modern energy sources is necessary for economic growth and improving living conditions at household level (World Bank, 2010) To meet basic human needs and alleviate poverty there is need to make efficient and reliable cleaner sources of energy available and accessible. A special except of the world Energy Outlook of 2010, noted that the United Nations MDG goal of eradicating extreme poverty by 2015 was not reachable without improving energy access (IEA/ UNDP/ UNIDO, 2010). This therefore implies that there is a link between source of energy used by house hold and poverty. Globally two million deaths occur from Pneumonia, chronic lung diseases and lung cancer which are associated with exposure to indoor air pollution resulting from the burning of biomass energy (crop residue, cow dung and fuel wood) in traditional ways (UNDP/ WHO, 2009).

Despite the importance of modern energy, half of the world population live without modern energy 1.5 billion people in developing countries lack access to electricity. This is as a result of the slowness to extend electricity to rural areas in a wide range of developing countries through grid extension, stand alone and mini grid approaches. It is estimated that more than $80 \%$ of people without electricity access live either in Sub-Saharan Africa or in South Asia. While SubSaharan Africa makes up about $14 \%$ of the total population of developing countries, it accounts for almost $40 \%$ of the population without access to electricity (UNDP/ WHO, 2009). An estimated 620 million people in Sub-Saharan Africa do not have access to electricity, and for those that do have it supply is often insufficient, unreliable and costly (OECD/ IEA, 2014).

The attempt to electrify Maza village began by NESCO company in 2001, using overhead electricity supply but the poles and cables passed by back farms through the villages. Between 2004 to 2005 Dr. Danladi Atu awarded contract when he was chairman of Jos North Local Government to supply the villages with step-down electricity, but the supply was just a clustered and supplied electric meters to about 23 houses which is not up to 30 percent. The cables were cut off and stolen during the night by thieves and the villages ended up not achieving the aim of the electricity supply up to date. In 2014 late 
Senator G.N.S. Pwajok through the Millennium Development Goal (MDG's) supplied transformer to Liba a village in Maza but up till now it's not connected. There is also lack of maintenance which resulted to the breakdown of electricity in Maza as a rural area.

\section{Clarification of Concepts}

The concepts requiring clarification here are three namely, energy poverty, hydro-electricity, and electricity growth and development.

\subsection{Energy Poverty}

Energy poverty is lack of access to modern energy services. It refers to the situation of large number of people in developing countries and some people in developed countries whose well-being is negatively affected by very low consumption of energy, use of dirty and polluted fuels and excessive time spent in collecting to meet basic needs. It is inversely related to access to modern energy services. Although improving accesses is only one factor as an effort to reduce energy poverty, because energy poverty is distinct from fuel poverty which focuses solely on the issue of affordability. According to the Energy Poverty Action Initiative of the World Economic Forum, "Access to energy is fundamental to improving quality of life and is key imperative of economic development". In the developing world, energy poverty is still rife. Nearly 1.6 billion people still don't have access to electricity, according to the International Energy Agency (IEA). As a result of this situation a new UN initiative has been lunched to coincide with the designation of 2012 as the International year for Sustainable Energy for all, which has a major focus on reducing energy poverty. Duke university has launched a research project of household energy and health where work on energy poverty in India is listed.

\subsection{Hydro-Electricity}

Hydro-electricity uses a water turbine to generate power. In 1878 the world first hydro-electric power scheme was developed at Crag side in Northernberland England by William George Armstrong. It was used to power a single arc lamp in his art gallery. The first Edison hydro-electric power plant was the Vulcan street plant, it began September 30, 1882 in Appleton, Wisconsin with an output of about 12.5 Kilowatts.

\subsection{Electricity, Growth, and Development}

Change in income often lead to changes in the demand for electricity and electricity generation. The causality between electricity and economic growth has pre-occupied energy economist for a number of years. Four type of causal relationship which exist between electricity and economic growth has been postulated in the recent literature (Ozturk, 2010). These consist of no relationship, which implies that a policy directed at each is irrelevant for the other. If their relationship is one where economic growth leads to growth in demand for electricity then policies directed towards conserving energy may have little effect on economic growth. If on the other hand electricity consumption leads to economic growth, then conserving energy may adversely affect economic growth. The most plausible relationship is likely to be in two directions and in this case the relationship between policies towards promoting growth, energy use and conservation are likely to be more complex. The difference are however, increasingly relevant as the ideas for sustainable development continues to generate thinking about future growth paths for developing countries. The initial relationship between energy consumption and economic growth was explored by the Kraft and Kraft (1978) in the U.S. since thence numerous studies in this field have used single country bivariate and multivariable models (which have included variables such as fixed capital formation or labour force ecetra).

\section{Conceptual Framework}

Rural electrification is the process of bringing electrical power to rural and remote areas. Electricity is used not only for lighting and household purposes, but it also allows for mechanization of many farming operations such as wellpumping, threshing, milking and hoisting grains for storage. In areas facing labour shortages, this allows for greater productivity and reduced cost, one famous was the new Deal Rural Electrification Administration created in 1936 in the United States, which pioneered many of the schemes still practiced in other countries.

A least a billion people worldwide still lack household electric power - a population equal to that of the entire world in the early 19th century. As of the mid 2010's an estimated 200 to 300 million people in India (15 to 20 percent of the population) lack electricity as well as seven out of eight rural Sub-Saharan Africans. Many more received only intermittent and poor-quality electric power. In 2012 some 23\% of people in East Java, Indonesia, a core region, also lack electricity as surveyed in 2013. It is estimated that the absolute number of people without power was growing until the late 1980's when rural electrification programme particularly in East Asia, outpaced the growth of human population. Up to about 1.84 billion in 1970, approximately 2.01 billion (equal to the world population in 1927) people in developing countries still lack household electric power in 1990 (the year the world wide web was invented) about 38 percent of the world population at that time. 51 percent of the population of so-called developing countries and 67 percent of rural parts of the developing world. The International Energy agency (IEA) estimates that if current trends do not change, the number of people without electricity will rise to 1.2 billion by 2030. Due to high population growth, the number of people without electricity is expected to rise in Sub-Saharan Africa.

\section{Reasons for Lack of Electricity in Maza Village}

An investigation was done to ascertain the reason for lack of electricity in Maza village, the result of this is presented in table 1. 


\begin{tabular}{|c|c|c|c|}
\hline S/ N & Reasons Why Maza Village is Without Electricity & Frequency & Percentage \\
\hline 1 & The dwellers don't need electricity & 0 & $0 \%$ \\
\hline 2 & People are not willing to pay for electricity & 0 & $0 \%$ \\
\hline 3 & The cost of electricity generation is high & 112 & $75 \%$ \\
\hline 4 & The power company do not want to electrify the community & 38 & $25 \%$ \\
\hline \multicolumn{2}{|c|}{ Total } & 150 & $100 \%$ \\
\hline
\end{tabular}

Table 1: Responses on Why Maza Village is without Electricity

Source: Fieldwork, October 2018

From the result presented in table 1 it can be said that the major reason why Maza village is still without electricity supply today is because of high cost of electricity (supply) as opined by $75 \%$ of the respondents only $25 \%$ are of the view that the power company don not want to electrify the community. An interview with some of the community members revealed that quite a number of residents of the community are in dare need of electricity and are willing to pay for it but the community is not connected to the national grid.

\subsection{The Implications of Lack of Electricity Supply for the Development of Maza Village}

The lack of electricity in Maza village has great consequences to the community. An investigation into some of the implications of the lack of power supply in community include shutting down of economic activities, problem of how to address various health challenges, poor academic performance of students in the community. The major implication is health challenges/ complications due to usage of other power sources like firewood and charcoal instead of electricity.

\begin{tabular}{|c|c|c|c|}
\hline S/ N & Implication of Lack of Electricity & Frequency & Percentage \\
\hline 1 & Affected economic activities & 27 & $18 \%$ \\
\hline 2 & $\begin{array}{c}\text { Lead to poor academic performance among students staying } \\
\text { in the community }\end{array}$ & 48 & $32 \%$ \\
\hline 3 & Lead to various health challenges & 61 & $41 \%$ \\
\hline 4 & Early closure of clinic and challenges with storing some drugs & & \\
\hline \multicolumn{2}{|c|}{ Total } & 150 & $100 \%$ \\
\hline
\end{tabular}

Table 2: Implication of Lack of Electricity in Maza Village Source: Fieldwork, October 2018

Table 2 presents the response on the implications of lack of electricity supply in Maza village. From this result, Majority $41 \%$ of the total respondents are of the view that the lack of electricity in the community has resulted into a lot of health challenges. They said because of the use of firewood and charcoal as a means for the residents of the community for heating and cooking due to lack of electricity, it has led to various respiratory ailments which are as the result of the incomplete combustion of the firewood and charcoal used. This finding is in line with the assertion of (Agba, 2010) where he opined that energy poverty is one of the contributions to poor health conditions and premature death in Sub-Saharan Africa and developing countries. According to the World Health Organization, cooking smoke from traditional biomass stove causes 95,300 deaths in Nigeria annually (Yao, 2010). World Health Organization (WHO) which estimates that 2.5 million women and children in developing countries die prematurely each year from breathing the fumes from biomass stoves. Traditional stoves used in rural and urban areas emit large amount of carbon monoxide and other toxic gases which account for acute respiratory illness affecting as much as 6\% of the world population (Agba, 2010).

Another major implication is poor academic performance among students staying in the community, $32 \%$ of the respondents affirmed to this. Some of the respondents who are students complained that they find it difficult to study at night without electricity as using candles or lamptarns is usually not conducive. They said doing assignments and some studies that entails them using computer will have them going somewhere else to look for power supply to use their computer or phones. $18 \%$ of the respondents alerted that the lack of electricity supply in the community affect economic activities while $9 \%$ are of the view that it leads to early closure of primary healthcare centers and difficulty in the storage of some drugs. All these problems associated with of electricity in Maza community have bought untold hardship on the people in this community.

\subsection{Attempts Made in the Past on How Maza Village Can Enjoy the Benefits of Electricity.}

Field results indicate that about $95 \%$ of respondents mentioned that attempts have been made in the past by different people to electrify the community and only $5 \%$ observed that they are without knowledge of any attempt made. From this result, it can be said that attempts have been made to electrify the community in the past but without any significant progress. (Figure 1 illustrates details of responses by the respondents). 


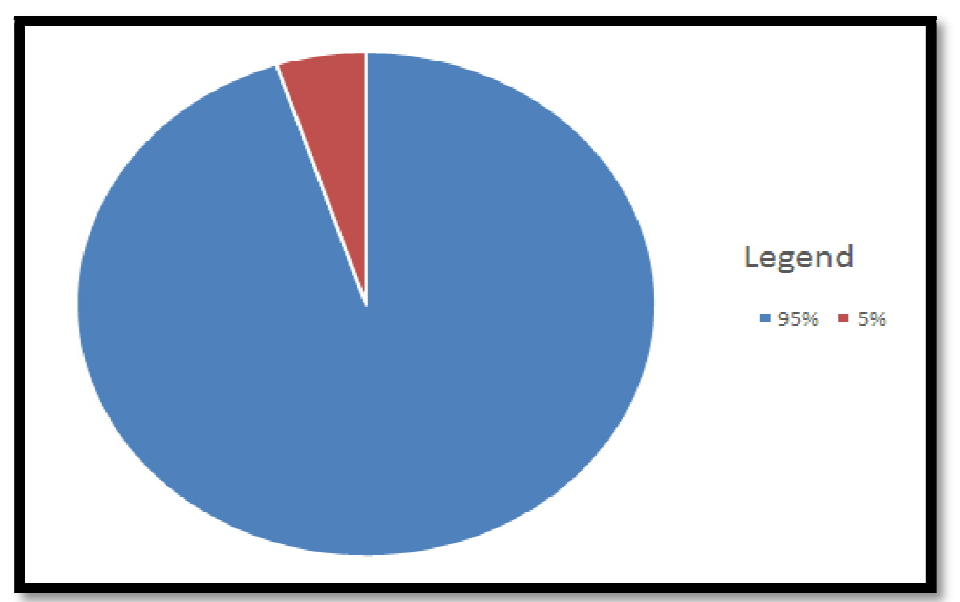

Figure 1: Responses on Attempts being made in Maza Village Source: Fieldwork, October 2018

When asked about who made any attempt to electrify the community, the result shows that different people in the past have made attempts but their efforts could not yield any result. First of all, the respondents said that many years ago, Nigeria Electric Power Authority (NEPA) came to the community and took some measurement while making a reconnaissance of the community, after then nobody heard from them again. Some stakeholders in the community made it clear that the y went to the authority (NEPA) to find a way of electrifying the village but they keep trebling and turning them around. Other respondents said that a transformer was donated to the community by late Senator G.N.S. Pwajok in a bid to fast track and reduce the cost of the electricity generation to the community but still nothing was done about it.

\subsection{Strategies for Achieving Sustainable Electrification in Maza Village}

On the needed strategies to electrify Maza village, the respondents advocated for communal launching, individual contribution towards the project and consideration of other alternative source of energy like solar. Others are of the view that committee should be set up and saddle with the responsibility of electrifying the village.

\section{Recommendation}

Based on the research outcome, the following recommendations are made.

- Energy poverty can be reduced through improving the availability of alternative and modern energy sources and increasing the access to those sources through reducing financial poverty. The government should come up with pro-poor energy policies and pro-poor solutions to energy problem.

- The government should increase more players in the energy sector. This can be done through fostering public and private sector partnership in the sector.

- Local communities can partner with private sector and government agencies to undertake the development of offgrid and standalone renewable energy projects to increase access for millions of Nigerians who do not have access to national grid nor live in proximity to it. To the private sector, the existing energy poverty provides a business opportunity. Private investors can complement and support government in the provision of infrastructure and renewable energy products to the majority of the population living off the electricity grid. More detailed planning for the development of each sub-sector of the renewable industry is needed. The large-scale wind sector, for example will require more government involvement whereas the small-scale solar industry can benefit from the private sector investment with minimal government incentive.

\section{Conclusion}

Despite the Nigeria's abundance of fossil and renewable energy resources, Nigeria still experience acute energy poverty. The either lack access to directly which is affecting livelihoods, lowering quality of life and hurting the economy.

\section{References}

i. Adenikinju, A. (2005). Analysis of the cost of infrastructure in a developing economy: The case of the electricity sector in Nigeria African Economic Consortium Research Paper 148, Nairobi.

ii. Agba M.S. (2010) Energy poverty and the leadership question in Nigeria: An overview and implication for the future, Journal of Public Administration and Policy Research vol.3(2) PP 48 - 51.

iii. Barnes DF (2007). The Challenge of Rural Electrification. In Barnes DF (Ed) The Challenge of Rural Electrification. Strategies for developing countries; Washington; Resour. Future 1:1 - 18.

iv. IEA/ UNDP/ UNDIDO (2010) "Energy Poverty - How to make modern energy accessible" Special Except of the World Energy Outlook 2010 for the UN General assembly for Millennium Development Goals OECD/ IEA, Paris, France

v. Mustonen S. (2010) Rural energy survey and scenario analysis of village energy consumptions a case study of Lao People's Democratic republic. Energy Policy, 38(2) 1040 - 1048.

vi. Pearce D, (1987). Rural electrification. Accelerating impacts with complementary services energy sustain development. 13, 38 - 42. 
vii. UNDP/WHO (2009). The energy access situation in developing countries. A Review Focusing on the least Developing Countries and Sub-Saharan Africa WHO/ UNDP.

viii. World Bank. (1996) Meeting the Challenges of Rural Energy and Development. Washington DC: World Bank.

ix. World Bank. (2010). Energy Poverty in Rural and Urban India: Are the energy poor also income poor? Policy.

x. Yadoo, A. (2010) The value of cooperatives in rural electrification energy policy, 36(6) 2941 - 2947. 